\title{
New evidence for the Palaeolithic on the island of Gökçeada (Imbros), Northeastern Aegean
}

\author{
Burçin Erdoğu ${ }^{1}$, Nejat Yücel ${ }^{2}$, Kerem Demir ${ }^{3}$ \\ 1. Department of Archaeology, Akdeniz University, 07058 Kampus Antalya, Turkey. \\ Email: berdogu@gmail.com \& burcinerdogu@akdeniz.edu.tr \\ 2. Prehistory Section, Istanbul University, Laleli-Fatih, Istanbul, Turkey. Email: enyucel@gmail.com \\ 3. Department of Archaeology, Pamukkale University, 20070 Kınık Denizli, Turkey. Email: keremd@pau.edu.tr
}

\begin{abstract}
:
Eksino, on the island of Gökçeada (Imbros) in the Northeast Aegean, is a new open-air site with evidence of Palaeolithic cultural remains. Stone tools collected by an initial survey have clarified an assessment of the site from the Lower Palaeolithic, and brought to light new evidence from the Middle Palaeolithic as well as transition to the Upper Palaeolithic. Eksino is probably one of the most significant Lower Palaeolithic tool collections in the North Aegean, and finds such as chopper or chopping tools and Acheulean bifacial handaxes from the site show that the North Aegean may be another possible dispersal route from hominids to Europe via the East and Northeast Mediterranean during the Lower Palaeolithic. Middle Palaeolithic finds are frequent in the site and finds resemble the typical Mousterian type which is characterized by discoidal cores, Levallois cores and flakes, scrapers, denticulates, notches and points. Upper Palaeolithic finds are rare in the site, and a bifacial leaf point and large crescent-shaped backed pieces made on blades may reveal the presence of the Middle-Upper Palaeolithic transition on the island. This new data from Palaeolithic Gökçeada is likely to fill key geographic gaps associated with the initial dispersal of hominins through the northeast Aegean islands.
\end{abstract}

Keywords: Island of Gökçeada (Imbros); North Aegean; Lower Palaeolithic; Middle Palaeolithic; Upper Palaeolithic

\section{Introduction}

Drawing on new data from a 1999 survey, this paper discusses evidence for Palaeolithic activity on the island of Gökçeada (Imbros), in the Northeast Aegean. Palaeolithic finds were discovered during a 1999 survey project on the Eksino (Değirmen) stream terraces and rock shelters on the eastern part of the island (Figures $1 \& 2$ ), close to the village of Eşelek (Harmankaya \& Erdoğu 2000: 30). Although some of these finds have been mentioned elsewhere before (Andreou \& Andreou 2017: 68-89; Erdoğu 2016; 2017; Özbek \& Erdoğu 2014), no detailed publication has been made. This study is based on previously unsystematically collected material that had not been examined so far. The Palaeolithic ISSN: 2055-0472. URL: http://journals.ed.ac.uk/lithicstudies/ 
material in Eksino is spread over an area of $c a .800 \times 500 \mathrm{~m}$ and consists mainly of four findspots shown in Figure 1.

The island of Gökçeada (Imbros) is about $17 \mathrm{~km}$ from the Gallipoli Peninsula and covers an area of $289.5 \mathrm{~km}^{2}$. Gökçeada is mountainous, with Mount Doruk (Elias) the highest point on the island at an altitude of $673 \mathrm{~m}$. Although occupation on the island goes back to the Palaeolithic, studies so far have concentrated on Neolithic and Bronze Age settlements. The Uğurlu excavation, in the west of the island, show an uninterrupted settlement from 6700 to 4300 BCE, while the Yeni Bademli excavation, in the northeast of the island, yielded Early Bronze Age finds contemporary with Troy sequences (Erdoğu 2014; 2016; 2017; Hüryilmaz 2006: 56-70).

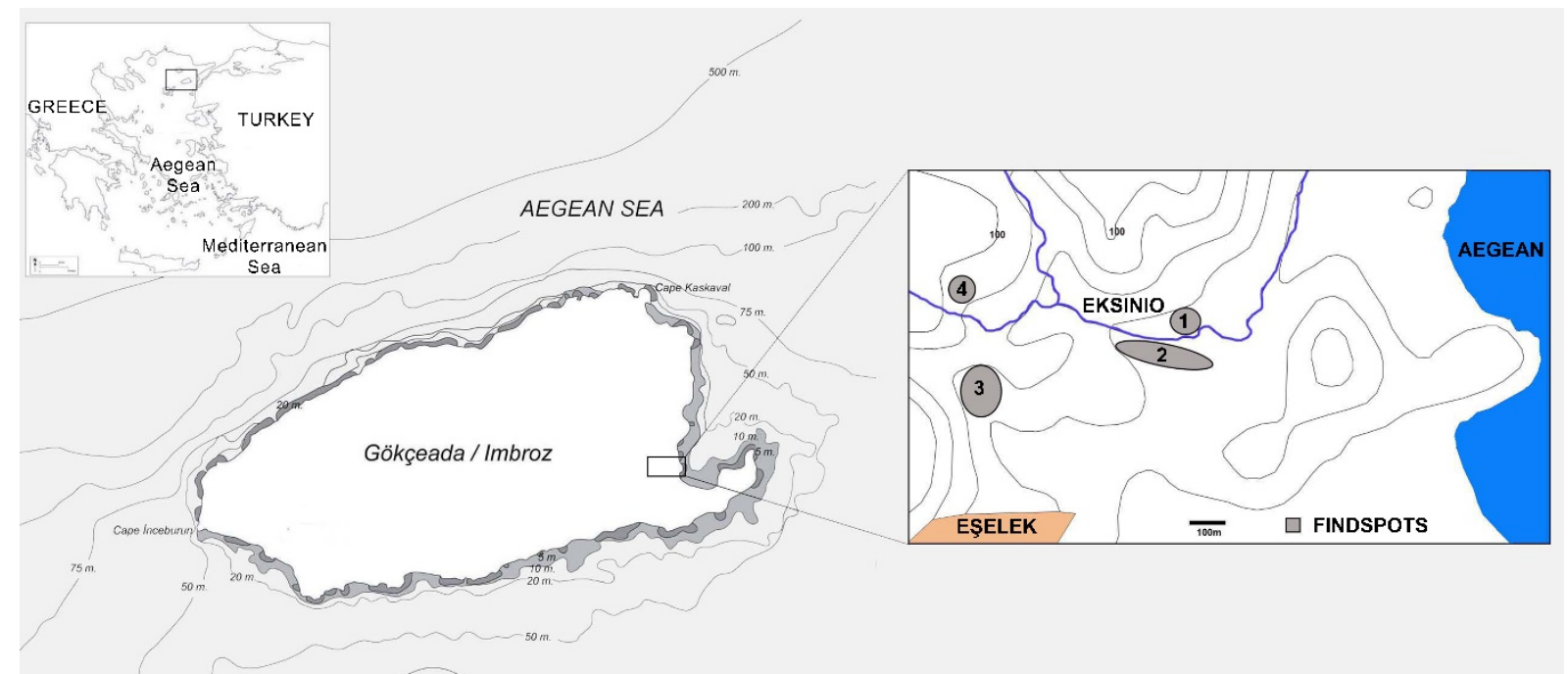

Figure 1. Map of the Eksino Region and Findspots where Palaeolithic finds were discovered in the east of Gökçeada Island.

Although the island has limited raw material sources, chert occurs on the eastern part of the island where Palaeolithic finds have been discovered (Sar1 et al. 2015). Chert is the main raw material for the manufacture of knapped tools that appears in large blocks and in a wide range of colours such as light brown, beige, bluish grey and red brown. Its quality varies: some blocks are almost impossible to knap because of natural cracks, while other are very fine grained and homogeneous.

Based on the techno-typological attributes of the stone tools collected by the early survey, it can be argued strongly that there was a presence of early occupation at Gökçeada during the Lower, Middle and Upper Palaeolithic. The Palaeolithic finds described in this paper highlights the potential to increase our understanding of early human engagement with the island of Gökçeada.

Recent Palaeolithic finds from the islands of Agios Efstratios and Lemnos suggest that glacial periods with low sea levels likely allowed the migration of hominins to the North Aegean (Sampson et al. 2018). During the Marine Isotope Stage (MIS) 8, 10 and 12, around 400-250 ka., the Aegean Basin consisted of an almost continuous land mass connecting Anatolia and the Greek mainland, with some large inland lake basins (Carter et al. 2019; Galanidou et al. 2020). During the Last Glacial Maximum (LGM), ca. 20 ka., the sea level was about 130-120 m lower than today, with the island of Gökçeada (Imbros), along with all other North Aegean islands, connected to the mainland (Chalkioti 2016; Özbek \& Erdoğu 2014). During the Younger Dryas, between 12,9-11.5 ka., sea levels were 55-60 m lower resulting in Gökçeada, and Lemnos, becoming connected by an isthmus (Chalkioti 2016; Perissoratis \& Conispoliatis 2003). 


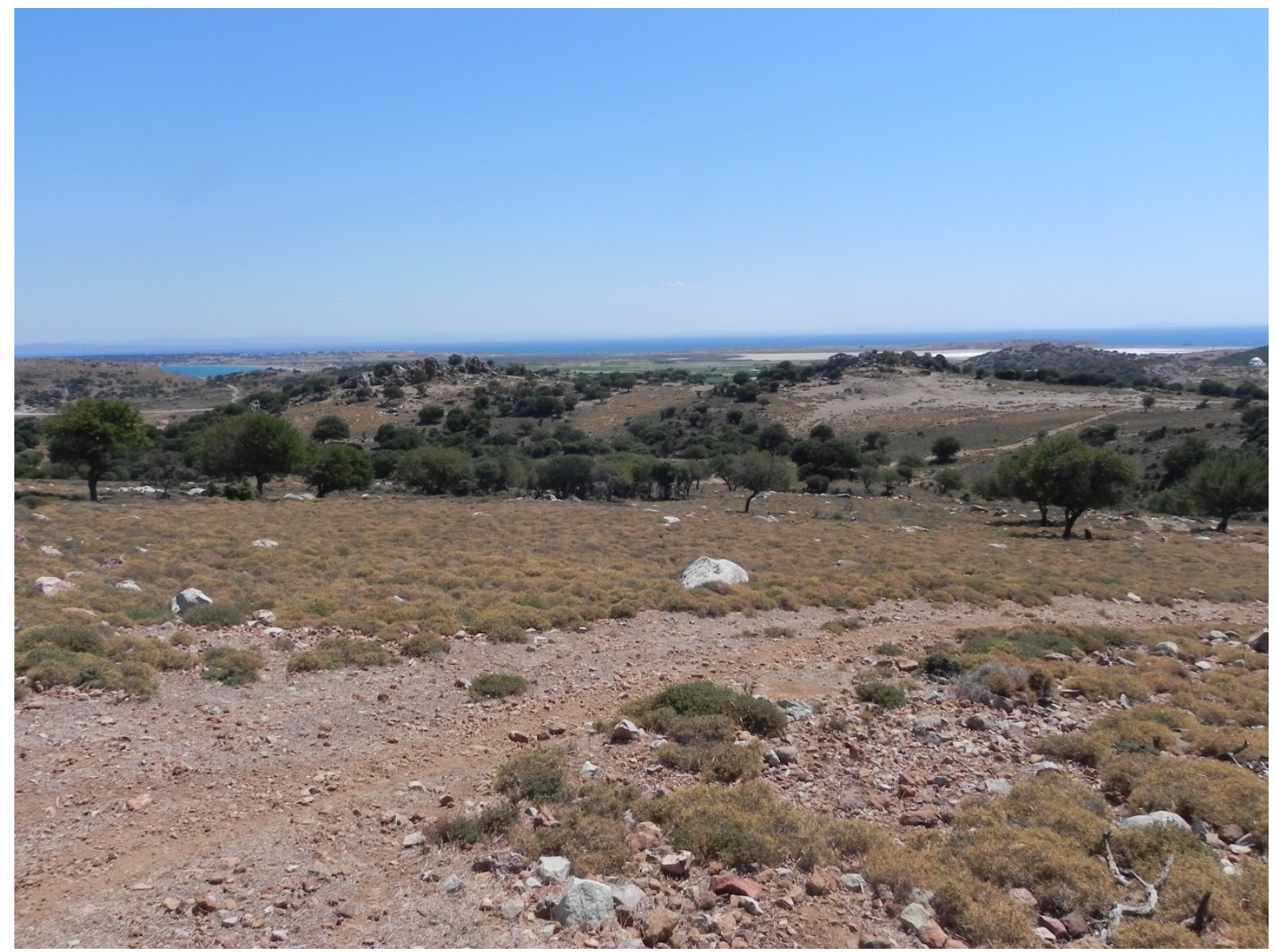

Figure 2. General View from Eksino Stream Terraces.

\section{Palaeolithic Finds from Gökçeada}

\subsection{Lower Palaeolithic}

The occupation of Gökçeada has its origins in the Lower Palaeolithic. It is characterized by a dominance of large flake-based picks and scrapers as well as chopper or chopping tools and cleavers (Figures $3 \& 4$; Table 1). A biface sharing typo-technological affinities with those of the Acheulean tool tradition is a unique find (Figure 4: 1). Lower Palaeolithic assemblages are previously unknown in the Northeast Aegean. Comparisons may be made with two nearby excavations. The Acheulean site at Rodafnidia-Lisvori on the island of Lesbos, in the East Aegean, is an important excavated site characterized by bifaces and cleavers dated to $272 \pm 25$ and $475 \pm 48 \mathrm{ka}$. (Galanidou et al. 2016). Bifaces have also been found in the İzmir region of coastal western Anatolia (Çilingiroğlu et al. 2016; Harmankaya \& Tanindi 1997). The lithic finds collected during the 1999 survey at Gökçeada show some similarities between artefacts from Eksino and those from Rodafnidia, i.e., the biface and cleavers. In comparison, chopper or chopping tools, typical of those found from Eksino, do not occur in Rodafnidia. Excavations at Yarimburgaz, dated between $390 \pm 40$ to $220 \pm 20$ ka., show a high frequency of retouched flake tools dominated by denticulate and sidescrapers as well as chopper or chopping tools (Kuhn et al. 1996). Chopper and chopping tool are abundant in Turkish Thrace as well as Bozyer near the Lake Marmara in the province of Manisa, except for the two unique atypical bifaces (Dinçer 2016; Roosevelt et al. 2019; Runnels \& Özdoğan 2001). Both chopper or chopping tools and bifacial handaxes are found on Gökçeada. 

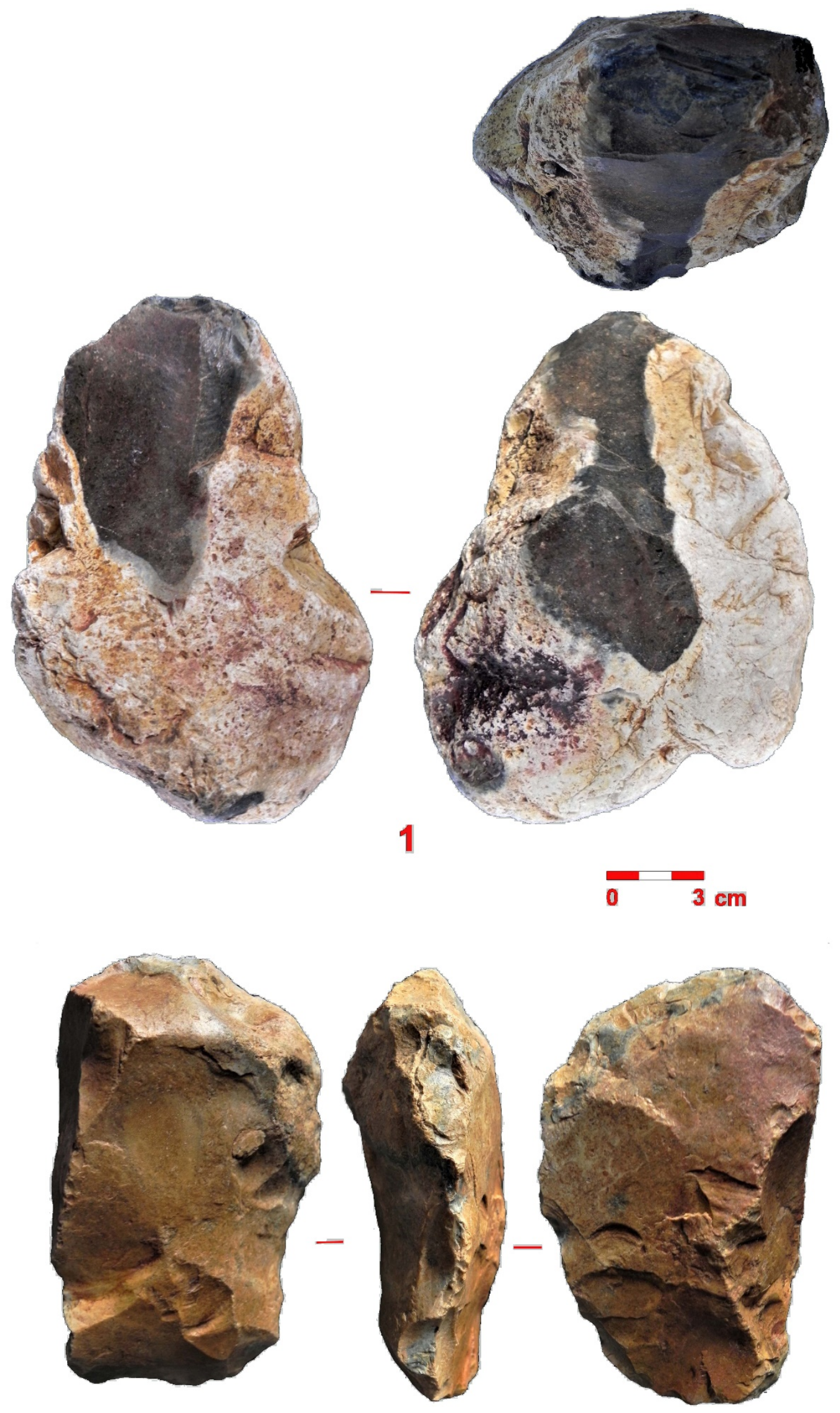

2

Figure 3. A chopper (1) and a cleaver and scraper (2). All artifacts made on chert. 

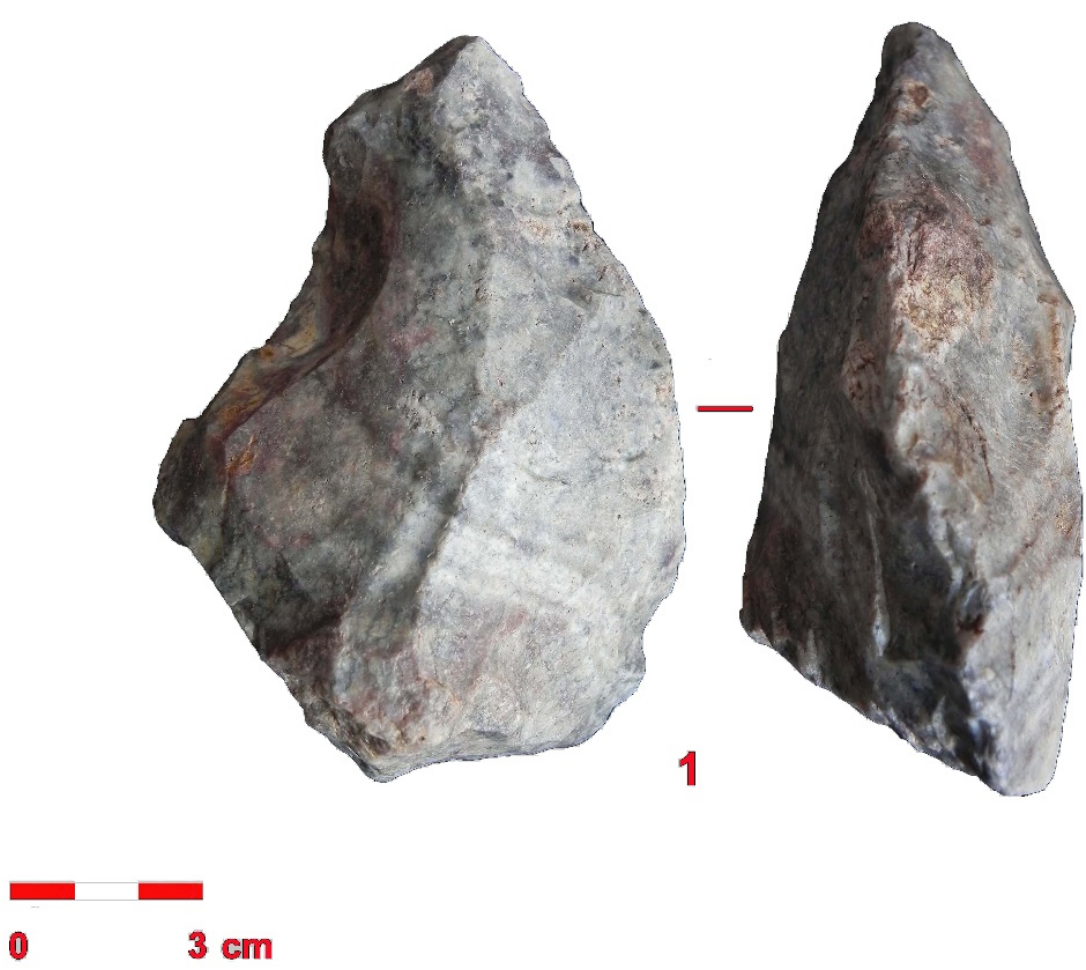

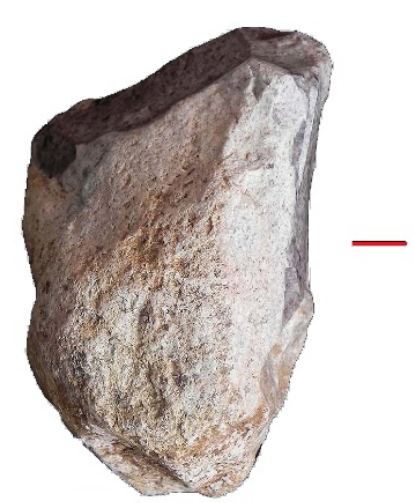

2

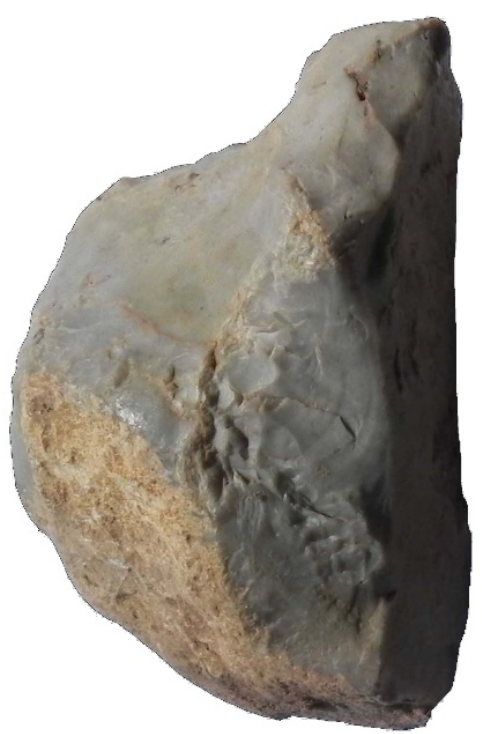

3

Figure 4. A biface (1), a copping tool (2) and a pick (3). All artifacts made on chert.

\begin{tabular}{lc} 
Table 1. The Lower Palaeolithic lithic collectio \\
\hline Type (Findspot 1) & Number \\
\hline Bifacial Handaxe & 1 \\
Chopper or chopping tool & 2 \\
Cleaver & 2 \\
Pick & 4 \\
Scraper & 1 \\
Other large tools & 2 \\
\hline
\end{tabular}

\subsection{Middle Palaeolithic}

Middle Palaeolithic finds are somewhat more frequent than Lower Palaeolithic finds. Middle Palaeolithic items are also widespread on the Northeast Aegean islands (Sampson et al. 2018), Cyclades (Carter et al. 2014), Thrace (Ammerman et al. 1999; Fotiadis 2016), Troas region and the Bozburun Peninsula of Western Anatolia (Atakuman et al. 2020; Özer et 
al. 2018). The Gökçeada finds resemble the typical Mousterian type which is characterized by discoidal cores, Levallois cores and flakes, scrapers, denticulates, notches and points (Figure 5; Table 2). End-scrapers with semi-circular fronts are characteristic. Transverse and dejete scrapers also occur. Levallois points are rare and a bifacial leaf point is a unique find (81.1 $\mathrm{mm}$ long and $29.3 \mathrm{~mm}$ wide) (Figures 6: 1). Bifacially flaked points have a wide geographical distribution and occur in Middle and Initial Upper Palaeolithic contexts. Their distribution and age have recently been investigated in detail by Fotiadis (2016). The Eksino leaf-point is similar to the Muselievo leaf-points in Bulgaria, ca. 50-45 ka. (Ivanova \& Sirakova 1995).

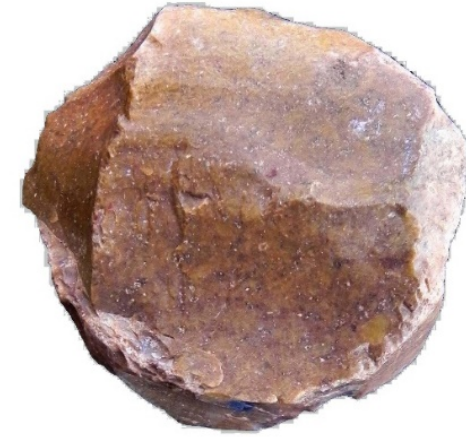

1

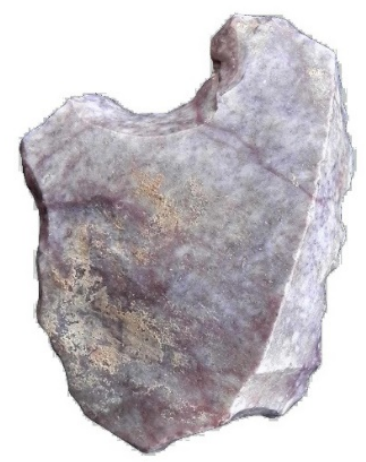

3

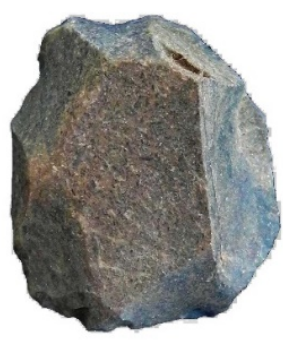

2

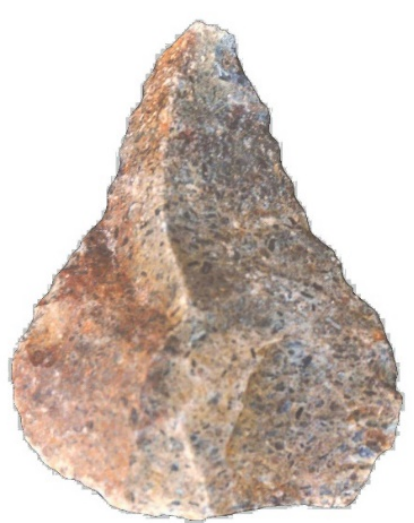

4



$0 \quad 3 \mathrm{~cm}$

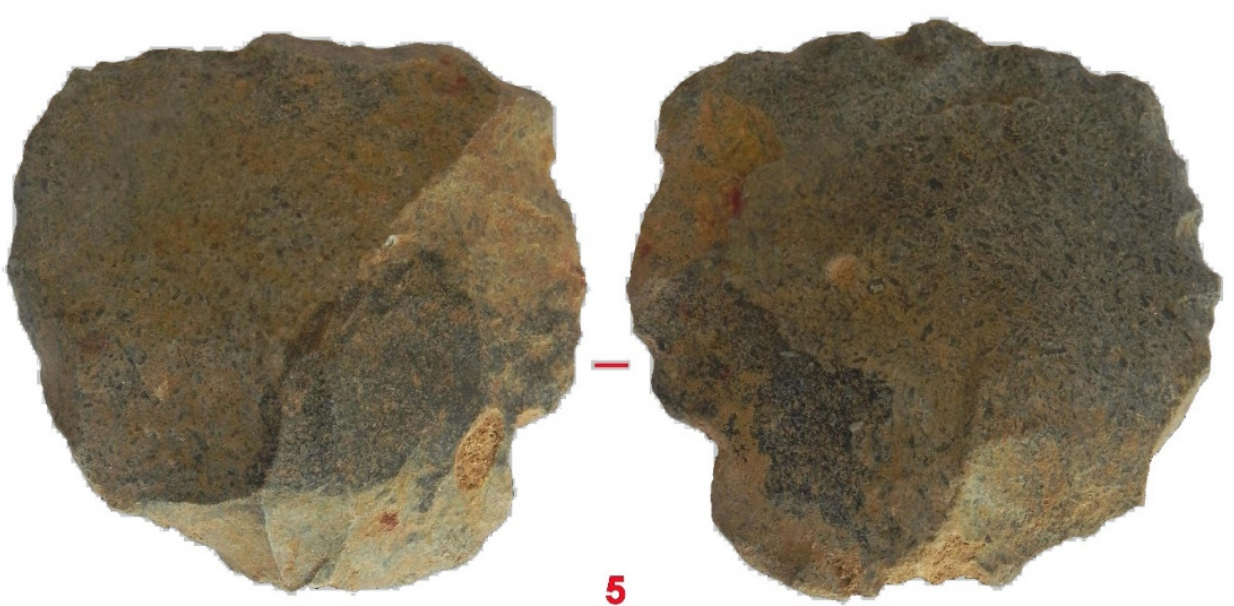

Figure 5. a Levallois core (1), a discoidal core (2), a denticulate and notch (3), a point (4) and an end-scraper with semi-circular front (5). All artifacts made on chert. 
Table 2. The Middle Palaeolithic lithic collection.

\begin{tabular}{lc}
\hline Type (Findspots 1-4) & Number \\
\hline Levallois core & 4 \\
Discoidal core & 4 \\
Mousterian point & 1 \\
Dejete scraper & 1 \\
Transverse scraper & 1 \\
Endscraper & 4 \\
Levallois flake & 2 \\
Burin & 1 \\
\hline
\end{tabular}
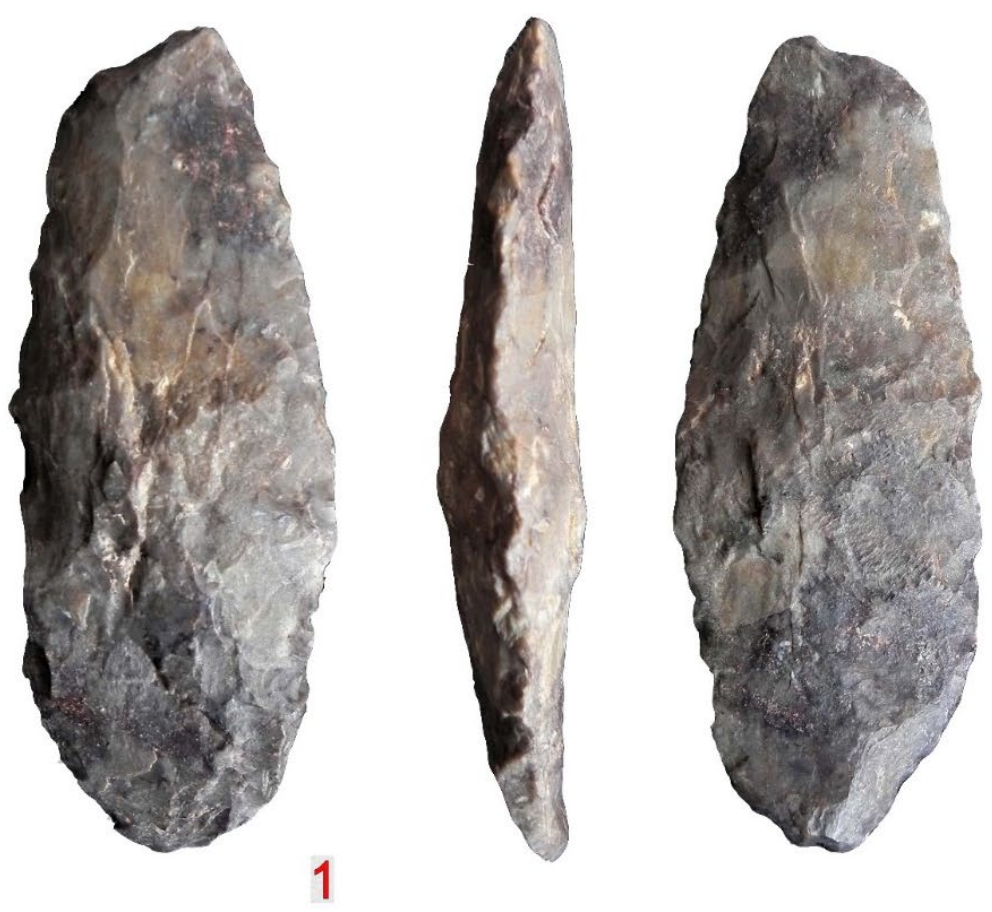

0

$3 \mathrm{~cm}$

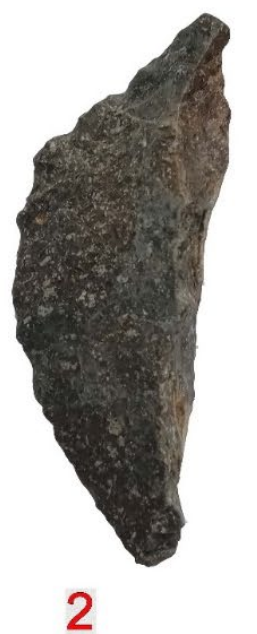

Figure 6. A bifacially flaked point (1) and a crescent-shaped backed piece (2). All artifacts made on chert. 


\subsection{Upper Palaeolithic}

Upper Palaeolithic finds are rare and consist of single platform blade cores (one pyramidal shape), an opposite platform core, a point, retouched blades and end scrapers (Figure 7; Table 3). In contrast, the Upper Palaeolithic assemblages in Western Turkey and the Aegean are highly debateable with material only relatively dated and subject to further revisions. Some Upper Palaeolithic finds were discovered during the Bozburun survey of Western Anatolia and on the island of Agios Efstratios in the North Aegean (Atakuman et al. 2020; Sampson et al. 2018).

Two large crescent-shaped backed pieces made on blades $(55.2 \mathrm{~mm}$ and $41.3 \mathrm{~mm}$ in length) were also discovered (Figure 6: 2). Similar, but smaller, backed pieces on blades have been observed in the Uluzzian transitional technocomplex, ca. 45 and $40 \mathrm{ka}$. (Moroni et al. 2013).

Table 3. The Upper Palaeolithic lithic collection.

\begin{tabular}{lc}
\hline Type (Findspot 2) & Number \\
\hline Single platform blade core & 3 \\
Opposite platform core & 1 \\
Point & 1 \\
Endscraper & 2 \\
Retouched blades & 4 \\
Backed pieces & 2 \\
\hline
\end{tabular}

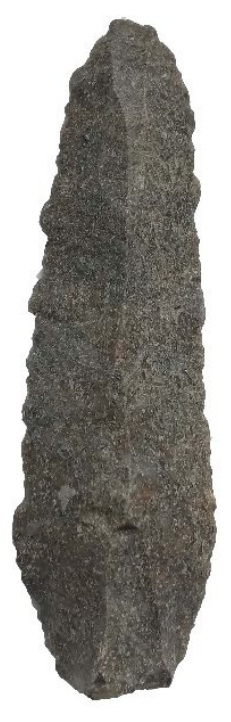

1

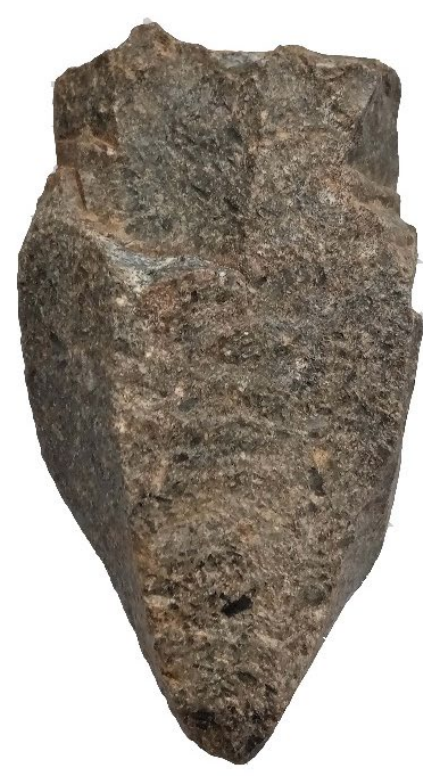

2

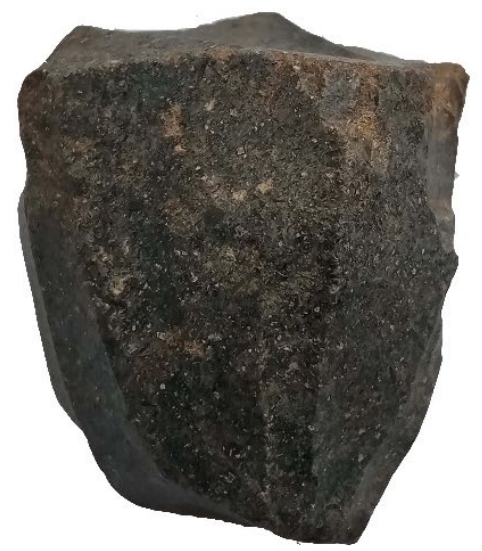

3



Figure 7. A point (1), a pyramidal shaped single platform blade core (2) and an opposite platform core (3). 


\section{Concluding remarks}

Eskino, on the island of Gökçeada, is a potential site that spans all periods of the Palaeolithic. After Rodafnidia-Lisvori, this is one of the most significant Lower Palaeolithic tool collections in the North Aegean. This site is of particular importance as there are few instances of Lower Palaeolithic finds throughout the entire Aegean islands (such as Crete, Gavdos, Melos and Naxsos) with affinities to the Acheulean techno-complex (Carter et al. 2019; Galanidou 2014). It has previously been accepted that the Aegean Sea was an impassable barrier for early hominids; the most likely entry point to Europe was the MarmaraThrace land corridor (Taşkıran 2018). The finds from Rodafnidia-Lisvori, and now Eksino, show that the North Aegean may be another possible dispersal route from hominids to Europe via the East and Northeast Mediterranean during the Lower Palaeolithic; a concept already suggested by Carter et al. (2019). Palaeogeographical reconstructions also suggest an extended continental shelf in the North Aegean during this period (Galanidou et al. 2020).

Aside from the few known sites mentioned above, the Aegean still has a sparse Middle Palaeolithic record (see Sampson et al. 2018; Tourloukis \& Harvati 2017). However, even this sparse record may suggest that the Aegean had a transitional role for Neanderthal movement between the east and the west. Timing of the arrival of modern humans in Europe and transitional industries such as the Bachokirian and the Uluzzian are matters of intense debate. A bifacial leaf point and large crescent-shaped backed pieces made on blades may reveal the presence of the Middle-Upper Palaeolithic transition on the island. Ultimately, further investigations and excavations need to be completed to improve our knowledge of the Palaeolithic record of Gökçeada.

\section{Acknowledgements}

We wish to thank Jarrad W. Paul for his kind corrections to the language in this paper.

\section{References}

Ammerman, A.J., Efstratiou, N. \& Adam, E. 1999, First evidence of Palaeolithic finds in Aegean Thrace, In: The Palaeolithic Archaeology of Greece and Adjacent Areas (Bailey, G.N., Adam, E., Panagopoulou, E., Perles, C. \& Zachos, K., Eds.), Proceedings of the ICOPAG Conference, Ioannina, British School at Athens Studies 3, British School at Athens, London: p. 211-15.

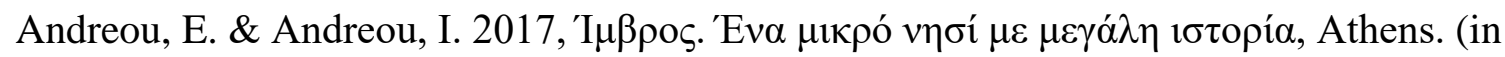
Greek) (Imbros: A small island with a long history)

Atakuman, Ç. Erdoğu, B., Gemici, H.C., Baykara, İ., Karakoç, M., Biagi, P., Starnini, E., Guilbeau, D., Yücel, N., Turan, D. \& Dirican, M. 2020, Before the Neolithic in the Aegean: the Pleistocene and the Early Holocene record of Bozburun - Southwest Turkey. The Journal of Island and Coastal Archaeology: 1-33. doi:10.1080/15564894.2020.1803458

Carter T., Contreras, D., Doyle, S., Mihailović, D.D., Moutsiou, T., \& Skarpelis, N. 2014, The Stélida Naxos Archaeological Project: new data on the Middle Palaeolithic and Mesolithic Cyclades. Antiquity Project Gallery, 88(341).

URL: https://antiquity.ac.uk/projgall/carter341

Carter, T., Contreras, D.A., Holcomb, J., Mihailović, D.D., Karkanas, P., Guérin, G., Taffin, N., Athanasoulis, D. \& Lahaye, C. 2019, Earliest occupation of the Central Aegean 
(Naxos), Greece: implications for hominin and Homo Sapiens' behavior and dispersals. Science Advances, 5(10): 1-9. Eaax0997. doi:10.1126/sciadv.aax0997

Chalkioti, A. 2016, Reconstructing the coastal configuration of Lemnos Island (Northeast Aegean Sea, Greece) since the Last Glacial Maximum. In: Géoarchéologie des îles de Méditerranée, (Ghilardi, M., Ed.), Paris: p.109-118.

URL: https://books.openedition.org/editionscnrs/28545

Çilingiroğlu, Ç., Dinçer, B., Uhri, A., Gürbıyık, C., Baykara, İ., Çakırlar, C. 2016, New Paleolithic and Mesolithic sites in the eastern Aegean; the Karaburun Archaeological Project. Antiquity Project Gallery, 90(353): E1. doi:10.15184/aqy.2016.168

Dinçer, B. 2016, The Lower Paleolithic in Turkey: Anatolia and hominin dispersals out of Africa. In: Paleoanthropology of the Balkans and Anatolia: Human Evolution and its Context. (Harvati, K., \& Roksandic, M. Eds.), Springer, Dordrecht: p. 213-228. doi:10.1007/978-94-024-0874-4_13

Erdoğu, B. 2014, Gökçeada Uğurlu Archaeological Project: A preliminary report from the 2011-2013 field seasons. Anatolica, XL: 157-178.

Erdoğu, B. 2016, The Neolithic landscape and settlement of the Island of Gökçeada (Imbros, Turkey)”, In: Géoarchéologie des îles de Méditerranée, (Ghilardi, M., Ed.), Paris: p. 89-94. URL: https://books.openedition.org/editionscnrs/28527

Erdoğu, B. 2017, A preliminary report on the earliest Neolithic levels at Uğurlu on the Island of Gökçeada. Anatolica, XLIII: 71-82.

Fotiadis, M. 2016, Leaf-points from Petrota (Greek Thrace) and the Palaeolithic chronology of the Vrahos chert quarry. The Annual of the British School at Athens, 111: 1-11. doi:10.1017/S0068245416000046

Galanidou, N. Athanassas, C., Cole, J., Iliopoulos, G., Katerinopoulos, A., Magganas, A. \& McNabb, J. 2016, The Acheulian site at Rodafnidia, Lisvori, on Lesbos, Greece: 20102012. In: Paleoantropology of the Balkans and Anatolia. Human Evolution and its Context, (Harvati K. \& Roksandic, M., Eds.), Springer, Dordrecht: p.119-138. doi:10.1007/978-94-024-0874-4_8

Galanidou, N. 2014, Advances in the Palaeolithic and Mesolithic archaeology of Greece for new millennium. Pharos, 20: 1-40. doi:10.2143/PHA20.1.3064535

Galanidou, N., Dellaporta, K., Sakellariou, D. 2020, Greece: unstable landscapes and underwater archaeology In: The Archaeology of Europe's Drowned Landscapes, (Bailey, G., Galanidou, N., Peeters, H., Jöns, H., \& Mennenga, M., Eds.), Cham, Springer International Publishing: p. 371-392. doi:10.1007/978-3-030-37367-2_19

Harmankaya, S., Tanindi, O. 1997. Türkiye Arkeolojik Yerleşmeleri (Paleolitik ve Epipaleolitik). Ege publishing, İstanbul. 290 p (in Turkish) (Archaeological Settlements in Turkey (Palaeolithic and Epi-palaeolithic)

Harmankaya S. \& Erdoğu, B. 2000, Prehistoric survey at Gökceada, Turkey, University of Durham and University of Newcastle Upon Tyne Archaeological Reports, 1999/2000: 28-35.

Hüryılmaz, H. 2006, Kuzeydoğu Ege Denizi’nin Rüzgarlı Bahçesi: Gökçeada, Çanakkale. (in Turkish) (The Windy Garden of the Northeast Aegean Sea: Gökçeada). 
Ivanova, S. \& Sirakova, S. 1995, Chronology and cultures of the Bulgarian Palaeolithic, In: Prehistoric Bulgaria (Bailey, D.W. \& Panayotov, I., Eds.), Monographs in World Archaeology 22, Madison, Wisconsin: p. 9-54.

Kuhn, S., Arsebük, G., \& Howell, F.C. 1996, The Middle Pleistocene lithic assemblage from Yarımburgaz cave, Turkey. Paleorient, 22: 31-49.

Moroni, A., Boscato, P., \& Ronchitelli, A. 2013, What roots for the Uluzzian? Modern behaviour in Central-Southern Italy and hypotheses on AMH dispersal routes. Quaternary International, 316: 27-44. doi:10.1016/j.quaint.2012.10.051

Özbek, O. \& Erdoğu, B. 2014, Initial occupation of the Gelibolu Peninsula and the Gokceada (Imbroz) Island in the Pre-Neolithic and Early Neolithic. Eurasian Prehistory, 11(1-2): 97-128.

Özer, İ., Sağır, M., Baykara, İ. Dinçer, B., Koca, B., Şahin, S., Eren, E., \& Özdemir, A. 2018, Çanakkale Ilinde Paleolitik Dönem Insan Izleri. DTCF Dergisi, 58.1: 99-116.(in Turkish) (Palaeolithic Human Traces in Çanakkale Province).

Perissoratis, C. \& Conispoliatis, N. 2003, The impacts of sea-level changes during latest Pleistocene and Holocene times on the morphology of the Ionian and Aegean seas (SE Alpine Europe), Marine Geology, 196: 145-156. doi:10.1016/S0025-3227(03)00047-1

Roosevelt, C., Dinçer, B., Luke, C., \& Çilingiroğlu, Ç. 2019, A Lower Paleolithic assemblage from western Anatolia: the lithics from Bozyer. Quaternary International, 522: 66-84. doi:0.1016/j.quaint.2019.05.016

Runnels, C. \& Özdoğan, M. 2001, The Palaeolithic of the Bosphorus region, NW Turkey. Journal of Field Archaeology, 28: 69-92. doi:10.1179/jfa.2001.28.1-2.69

Sampson, A., Kabouroglou, E., Kaczanowska, M. \& Kozlowski, J.K. 2018, Presence of Neanderthals on the Island of Agios Efstratios and Probable Networks of Contacts in the Northeastern Aegean during the early Middle Palaeolithic. Annals of Archaeology, 1(1): 39-56.

Sarı, R., Türkecan, A., Dönmez, M., Küçükefe, Ş., Aydın, Ü., \& Özmen, Ö. 2015, The geology of Gökçeada (Çanakkale). Bulletin of the Mineral Research and Exploration, 150: 1-18. doi:10.19111/bmre.42119

Taşkıran, H. 2018, The distribution of Acheulean culture and its possible routes in Turkey. CR Palevol 17: 99-106 .doi:10.1016/j.crpv.2016.12.005

Tourloukis, V. \& Harvati, K. 2017. The Palaeolithic record of Greece: a synthesis of the evidence and a research agenda for the future. Quaternary International, 466: 48-65. doi:10.1016/j.quaint.2017.04.020 